\title{
Tanning capacity of Tessmannia burttii extracts: the potential eco-friendly tanning agents for the leather industry
}

\author{
Cecilia R. China ${ }^{1 *}$ D, Stephen S. Nyandoro², Joan J. E. Munissi², Mihayo M. Maguta ${ }^{3}$, Michael Meyer ${ }^{4}$ and \\ Michaela Schroepfer ${ }^{4}$
}

\begin{abstract}
In the present study, the tannins from stem and root barks of Tessmannia burttii Harms (Caesalpiniaceae), a plant species abundantly growing in Tanzania and other parts of Africa, were investigated for their suitability in hides tanning. Tannin powder was extracted at selected temperatures $\left(30,50\right.$ and $\left.80^{\circ} \mathrm{C}\right)$ and the influence of each temperature on the crosslinking capacity was evaluated. The interaction mechanism between hide powder collagen and the tannins was studied by Differential Scanning Calorimetry (DSC), trinitrobenzensulfonic (TNBS) acid assay and amino acid hydrolysis methods. Extraction temperatures showed low influence on crosslinking capacity of the tannins. However, extract obtained at $50^{\circ} \mathrm{C}$ exhibited best performance in terms of gap size between $\mathrm{T}_{\text {onset }}$ and $T_{\text {peak. }}$. The stem bark extract yield was higher than that from the root bark, but both were within the recommended ranges. The tannin content (61\%) of T. burttii stem bark extract was above recommended value (10\%), whereas its total phenolic content and total flavonoic content were found to be above that of commercial Acacia mearnsii tannin. The study of cross-linking parameters as a function of $\mathrm{pH}$ showed cross-linking to occur via a covalent mechanism at the basic amino groups. However, the bonds were not resistant to acid hydrolysis. The observed interaction mechanism indicated that tannins from stem and root barks of $T$. burttii belong to the condensed tannin, similar to A. mearnsii (black wattle), a commercial tannin source that was used in this study as a reference. Findings from this study depict that $T$. burttii extracts are auspicious eco-friendly alternative source of vegetable tannins to overcome the use of chromium salts in the leather industry.
\end{abstract}

Keywords: Tessmannia burttii, Caesalpiniaceae, Leather industry, Vegetable tanning, Tanning capacity

\section{Introduction}

Currently, chromium $(\mathrm{Cr})$ tanning technology is taking a lead in the leather industry, contributing to $90 \%$ of the leather tanned worldwide [1-3]. However, this technology poses waste disposal challenges to the leather industry associated with public health and environmental concerns. The situation calls for the growing demand to embark on sustainable and green manufacturing processes [4]. As such vegetable tannins have sparked the

\footnotetext{
*Correspondence: rolencec@gmail.com

'Division of Textile and Leather Technologies, Tanzania Industrial Research and Development Organization, P. O. Box 2355, Dar es Salaam, Tanzania Full list of author information is available at the end of the article
}

search for more sources that guarantee unlimited supply for sustainability of the leather industry globally. Use of vegetable tannins as tanning agents is deemed to be economical, environmentally friendly and sustainable because they are cheap, non-toxic and renewable $[5,6]$, hence considered as an alternative to chromium tanning.

Vegetable tanning takes place either through hydrogen or covalent bonding between the tannins and the functional groups of the skin collagen, which in turn stabilizes the hide and convert it into leather [6]. It is well known that the reactivity of functional groups in collagen towards tannins is highly dependent on the $\mathrm{pH}$ of the reaction medium. Additionally, it is acknowledged 
that cations in the solution preferentially react with carboxyl groups in collagen fibers while anions selectively react with amino groups [7]. Since vegetable tannins are anions in nature [8], they react preferably with amino groups, either protonated or unprotonated rather than carboxyl groups of the collagen [9]. Although several studies have reported the tanning capacity and interaction mechanism of the extract from different plant species [9-13], they represent infinitesimal fraction of available potential of the vegetable tannin sources. Therefore, there is huge reservoir of unexploited plants from different parts of the world with significant amount of tannins that need to be studied for their chemistry as well as their potential industrial applications including in the leather industry.

Tanzania is endowed with plethora of plants with their applications largely being limited to traditional medicine and other non-industrial economic utilizations [14], while their use in leather processing is seldomly known. Currently, only wattle tree is considered as a sole source of tannins in the country and its demand in the world market is high, thus depriving low income countrymen with effective access to the tree [15]. Exploring new plant materials for vegetable tanning is essential for the sustainability of the leather industry of Tanzania and beyond. In this regard, a plant species Tessmannia burttii Harms (Caesalpiniaceae) was included in our on-going investigations of vegetable tannins from the locally available plants.

T. burttii is among the dominating plant species found in the coastal forests of Tanzania [16]. The species is also distributed in other African countries such as Zambia, Zimbabwe and Democratic Republic of Congo [17]. Inspired by the presence of catechinoids among other constituents from the stem and root barks of the T. burttii (unpublished work) suggesting a high number of polyphenols (tannins), the extracts therefrom were screened for their potential tanning capacity for stabilizing collagen of the hide in leather processing. The screening in this study focused on studying the influence of extraction temperature on crosslinking capability of the tannins from T. burttii root and stem bark extracts. The tannin-collagen interaction mechanisms of the extracts were also explored to further establish the tannin type of the same extracts.

\section{Materials and methods}

\subsection{Materials}

\subsubsection{Plant materials and hide powder}

Barks from both roots and stems of T. burttii used for extraction of tannins were collected on 23rd November, 2014 from Zeraninge Forest Reserve (Altitude $300 \mathrm{~m}$; GPS 37 M 0454993 UTM 9321617), Bagamoyo District in Pwani Region, Tanzania. The plant was identified by
Frank M. Mbago in the field then authenticated at the Herbarium, Botany Department of the University of Dar es Salaam where the voucher specimen is deposited and given the reference number FMM 3686. Acacia mearnsii stem bark extract used as reference in this study are as those reported in our previous work [15]. Hide powder was kindly bestowed by FILK - Forschungsinstitut für Leder und Kunststoffbahnen (Research Institute of Leather and Plastic Sheeting), Freiberg, Germany.

\subsubsection{Chemicals and reagents}

All used chemicals and reagents which included 2,4,6trinitrobenzenesulphonic acid, sodium carbonate, hydrochloric acid, citric acid, disodium hydrogen phosphate, Mcllvain buffer, hydrochloric acid AR (38\%), monosodium phosphate, disodium phosphate, sodium hydrogen carbonate, lithiumcitrate buffer, ninhydrin, FolinCiocalteu's phenol reagent, gallic acid, aluminium chloride, catechin and sodium nitrite were of analytical grade purchased from Sigma Aldrich, Germany.

\subsection{Methods}

All analyses reported in this study were conducted in the analytical chemistry laboratory at the FILK-Research Institute of Leather and Plastic Sheeting, Freiberg, Germany.

\subsubsection{Preparation of root and stem barks}

The roots and stems were debarked then chopped into small pieces. The bark pieces were dried under the shade at Chemistry Department, University of Dar es Salaam for 2 weeks. The dried barks were pulverized to a particle size of equal or less than $1 \mathrm{~mm}$.

\subsubsection{Extraction of tannins}

Pulverized stem and root barks of T. burttii were subjected to extraction. Maceration extraction method [18] was employed with minor modifications. Approximately $20 \mathrm{~g}$ of the root and stem bark samples were separately sopped in $200 \mathrm{~mL}$ of distilled water in a glass beaker shielded with aluminium foil to preclude water evaporation. The mixture was placed on a water bath ready for the extraction exercise. Extraction was done at three distinct temperatures $\left(30,50\right.$ and $\left.80^{\circ} \mathrm{C}\right)$, the procedure which was adopted from our previous work [15]. The sample mixture was continuously stirred using an overhead stirrer which was connected to the beaker's opening through a hole created on the aluminium foil used to cover the sample. Extraction process was performed for $4 \mathrm{~h}$ and then the filtrates were collected. The bark residue were again subjected to second round of extraction for $4 \mathrm{~h}$. Therefore, $8 \mathrm{~h}$ were spent to leach tannins from one batch of the barks. Time for extraction for each step was chosen to be $4 \mathrm{~h}$ to allow a longer contact 
time between the milled barks and water. Extracts were lyophilized and resultant powder (tannin) was used for studying the influence of extraction temperature and $\mathrm{pH}$ on crosslinking capacity, and interaction mechanism with hide collagen. Preparation of $A$. mearnsii extract and resulting powder used as reference in this study was achieved as recently reported [15]. The extracted tannins powder was analyzed for extract yield, tannin content (TC), total phenolic content (TPC) and total flavonoid content (TFC).

Extract yield was determined using the following equation;

$$
\% \text { Extract yield }=\frac{\text { Extract obtained }(g)}{\text { Amount of moisture free barks used }(g)} \times 100
$$

\subsubsection{Determination of tannin content}

A standard procedure as described by Atkin and Thompson [19] was used to determine tannin content. In this method, unfiltered tannin solution was detanned by lightly chromed Freiberg Hide Powder batch number 'VK 383 '. In order to prevent the hide powder from passing through the capillary, a little dry cotton-wool was placed at the upper part of the bell. The neck was fixed with rubber stopper carrying capillary glass tube bent twice at right angles. Afterwards, $7 \mathrm{~g}$ of hide powder was filled in the bell and pressed outward onto the bell's wall to prevent channels that may allow tannin solution to pass through undetanned solution. The prepared filter bell was placed in $200 \mathrm{~mL}$ beaker and the latter was filled with tannin solution and placed in the water bath maintained at $18{ }^{\circ} \mathrm{C}$. When the tannin solution was ready absorbed by hide powder up to the neck, moderate suction was applied to the capillary limb until liquid flows out gradually at the rate of $8-10$ drops per minute. It was observed that, the detanned solution didn't produce turbidity with gelatin-salt reagent. The first $30 \mathrm{~mL}$ of the detanned solution was discarded and $50 \mathrm{~mL}$ of the next $60 \mathrm{~mL}$ was evaporated and dried to constant weight in order to establish the non-tannin content. The tannin content of the resultant extract was determined using the following formula:

Tannin content $=$ Soluble substances - non tannins

\subsubsection{Determination of Total phenolic content}

To determine the Total Phenolic Content (TPC), a previously established method was used [20]. To $0.2 \mathrm{~mL}$ of extract solution, $5 \mathrm{~mL}$ of $10 \%$ Folin-Ciocalteu's phenol reagent was added and thoroughly mixed followed by addition of $4 \mathrm{~mL}$ of $7.5 \%$ sodium carbonate after $6 \mathrm{~min}$. The mixture was diluted to $25 \mathrm{~mL}$ with deionized water and incubated for $90 \mathrm{~min}$. UV-VIS spectrophotometer
(Evolution 201) was used to record absorbance at 760 $\mathrm{nm}$. The calibration curve was obtained using gallic acid where the used concentrations were $50,75,100,125$, $200 \mathrm{mg} \mathrm{mL}^{-1}$. TPC was presented as $\mathrm{mg}$ gallic acid equivalent per g dry weight of the barks and then presented as percentage based on bark dry weight.

\subsubsection{Determination of Total flavonoid content}

The total flavonoid content in the resultant extract was attained using previously instituted procedure [21]. To $0.5 \mathrm{~mL}$ of extract solution $4 \mathrm{~mL}$ of deionized water was added followed by $0.3 \mathrm{~mL}$ of $5 \% \mathrm{NaNO}_{2}$ solution. After $5 \mathrm{~min}, 0.3 \mathrm{~mL}$ of $10 \% \mathrm{AlCl}_{3}$ solution was added. The solution was allowed to stand for $6 \mathrm{~min}$, then $2 \mathrm{~mL}$ of $1 \mathrm{M}$ $\mathrm{NaOH}$ solution was added. Lastly, the volume was made to $10 \mathrm{~mL}$ using deionized water and left to stand for 15 min followed by absorbance measurement at $510 \mathrm{~nm}$ using UV-VIS-spectrophotometer (Evolution 201). The calibration curve was obtained using $20,40,60,80,100$ $\mathrm{mg} \mathrm{mL}^{-1}$ concentrations of catechin. The TFC was expressed as $\mathrm{mg}$ catechin equivalent per $\mathrm{g}$ dry weight of the barks and then presented as percentage based on bark dry weight.

\subsubsection{Preparation of hide powder crosslinked with extract leached at different temperatures}

Hide powder was treated with the tannin powder prepared from the studied barks by employing an already established procedure [9]. In brief, approximately $1 \mathrm{~g}$ of hide powder was sodden in $20 \mathrm{~mL}$ of $0.4 \mathrm{M}$ Mcllvail buffer at $\mathrm{pH} 5$ for $1 \mathrm{~h}$ followed by addition of $5 \% \mathrm{w} / \mathrm{v}$ of the tannin powder extracted at three distinct temperatures. The solution was then shaken in the mechanical shaker at $35^{\circ} \mathrm{C}$ for $5 \mathrm{~h}$ followed by filtration using a vacuum pump. The filtrates were then discarded and treated hide powder was washed three times with excess water, soaked in phosphate buffer at $\mathrm{pH} 7$ and was reserved for further analysis.

\subsubsection{Preparation of hide powder crosslinked at different $\mathrm{pH}$}

The tannin powder prepared from studied barks was used to crosslink hide powder as per protocol described by Schropfer and Meyer [9]. About $1 \mathrm{~g}$ of hide powder was soaked in $20 \mathrm{~mL} 0.4 \mathrm{M}$ Mcllvail buffer at varying $\mathrm{pH}$ (2.5-9.0) for $1 \mathrm{~h}$. About $5 \% \mathrm{w} / \mathrm{v}$ of the tannin powder extracted at $50{ }^{\circ} \mathrm{C}$ was added, and the solution was shaken in the mechanical shaker at $35^{\circ} \mathrm{C}$ for $5 \mathrm{~h}$. The solution was then filtered using a vacuum pump. Filtrates were discarded and treated hide powder was washed three times with excess water, soaked in phosphate buffer at $\mathrm{pH} 7$ and was reserved for further analysis. 


\subsubsection{Differential scanning calorimetry (DSC) analysis of crosslinked hide powder}

The denaturation temperature of the crosslinked hide powder was measured using DSC 1 device (Mettler-Toledo) to determine the crosslinking capacity of the tannins against $\mathrm{pH}$ of the tanning solution. About $6 \mathrm{mg}$ (calculated on dry weight) of wet cross-linked hide powder was placed in an aluminium pan and then hermetically closed. Temperature scans were run from 10 to $125^{\circ} \mathrm{C}$ at a rate of $5{ }^{\circ} \mathrm{C} \mathrm{min}^{-1}$. Finally, the onset temperature $\left(\mathrm{T}_{\text {onset }}\right)$ and peak temperature $\left(\mathrm{T}_{\text {peak }}\right)$ were calculated based on the endotherms.

\subsubsection{TNBS assay}

2,4,6-Trinitrobenzenesulfonic (TNBS) acid assay was carried out using the experimental protocol developed by Schroepfer and Meyer [9] to determine the amount of basic amino groups crosslinked with the tannins from investigated plant extracts. Approximately $5 \mathrm{mg}$ of the cross-linked hide powder ( $\mathrm{pH} 7)$ was incubated in 200 $\mathrm{mL}$ of $0.5 \mathrm{M}$ sodium hydrogen carbonate buffer at $\mathrm{pH} 8$ and then $200 \mathrm{~mL}$ of $0.5 \%$ TNBS acid was added into the mixture. The samples were incubated at $60^{\circ} \mathrm{C}$ for $4 \mathrm{~h}$ to provide a room for TNBS acid to bind on the free primary amines (deprotonated) in the hide powder collagen. Afterwards, the mixture was hydrolyzed with $6 \mathrm{~N}$ $\mathrm{HCl}$ at $80^{\circ} \mathrm{C}$ for $1.5 \mathrm{~h}$, then diluted with $1 \mathrm{~mL}$ of distilled water and centrifuged at $14000 \mathrm{rpm}$. Then photometric measurements of supernatants absorption was performed at $400 \mathrm{~nm}$ using UV-VIS-spectrophotometer (Evolution 201). Quantification of crosslinked amino groups was performed by calibration with an alanine standard. The number of free primary amines of crosslinked and non-cross-linked hide powder samples were used as the basis to calculate the number of primary amines bound by the tannins using the equation below:

$$
=\frac{\begin{array}{l}
\% \text { of crosslinked amino groups } \\
100-\text { free amines }(\mu \mathrm{mol} \text { per } \mathrm{g} \text { dry sample })
\end{array}}{\text { mean value free amines }(\mu \mathrm{mol} \text { per g dry hide powder })} \times 100
$$

\subsubsection{Amino acid hydrolysis}

The perdormance of amino acid analysis aimed to identify the resistance of the basic amino groups crosslinked by tannins from the plant extracts under investigation to acid hydrolysis. Crosslinked hide powder samples were hydrolysed with $6 \mathrm{~N} \mathrm{HCl}$ at $110^{\circ} \mathrm{C}$ for $20 \mathrm{~h}$. Afterward, hydrolized samples were dried and dissolved in lithiumcitrate buffer. An amino acid analyser (Biochrom 30+) was employed to determine the amino acid composition in the cross-linked and non-cross-linked samples using pre-column derivatisation with ninhydrin according to the standard protocols [22]. The amount of primary amines formed an acid hydrolysis stable bond was calculated from the area under the lysine, hydroxylysine or arginine peaks and standardized to the area under the peaks from alanine and valine (these were not involved in cross-linking). The resulting percent of crosslinked amino groups were related to that calculated from noncross-linked sample.

\subsubsection{Quality control and assurance}

The quality and accuracy of the analytical results were monitored by analysing each sample in duplicate as well as analysing reference materials. Double deionized water was used for solution preparation, extraction of tannins and washing glassware to ensure that the solutions and tannins are free from contaminants. In order to monitor contamination, the reagent blank was analysed parallel with all samples analysed in this study. Barks were subjected to two extraction steps to ensure extraction efficiency. After extraction, extract solution was stored at $4{ }^{\circ} \mathrm{C}$ in the refrigerator to prevent bio-degradation of tannins that would lead to the loss of tanning ability. The dried extract powder was stored in an opaque container to prevent photo-oxidation of the tannins.

\section{Results and discussion}

\subsection{Effect of extraction temperature on crosslinking capacity}

Temperature applied during extraction of tannins from plant materials is an important parameter to consider as it determines the availability of phenolics and other reactive species [23]. The effect of temperature on crosslinking capacity was determined by crosslinking hide powder with the tannin powder extracted at different temperatures $\left(30^{\circ} \mathrm{C}, 50{ }^{\circ} \mathrm{C}\right.$ and $\left.80^{\circ} \mathrm{C}\right)$ and the results are presented in Fig. 1a. The influence of the extraction temperature on crosslinking capacity was observed to be insignificant for both root and stem bark within the studied temperature range. The observations were similar to those of commercial tanning source (A. mearnsii bark extract) used in this study as a reference plant extract (Fig. 1b). Moreover, the results are in accordance with those we recently reported for other plant extracts as potential sources of tannining agents [15]. However, in terms of $\mathrm{T}_{\text {peak }}$ and $\mathrm{T}_{\text {onset }}$ intervals, it is worth noting that the extract obtained at $50^{\circ} \mathrm{C}$ is better than the others because it leads to a crosslinked hide powder with the lowest interval between the two temperature points, suggesting high crosslinking capacity (Table 1 ). The value is very close to that of hide powder treated with $A$. mearnsii bark extract leached at $50{ }^{\circ} \mathrm{C}$ (Table 1). It is well known that the interval between $\mathrm{T}_{\text {onset }}$ and $\mathrm{T}_{\text {peak }}$ is an indicative of the extent of crosslinking process homogeneity, whereby the lower the interval the higher the homogenous the crosslinking process. This also gives a 

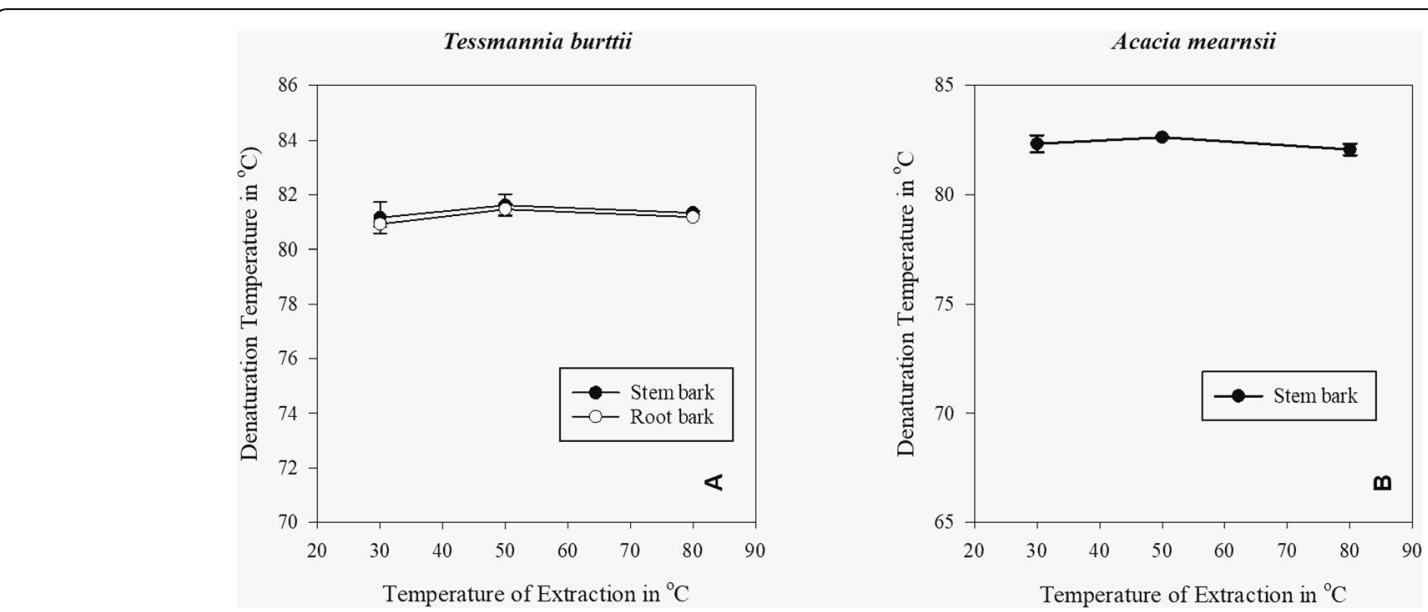

Fig. 1 Denaturation Temperature $T_{\text {onset }}$ of hide powder cross-linked with extract of Tessmannia burttii (a) and Acacia mearnsii (b) at pH 5 with dependence to temperature of extraction

clue on the crosslinking capacity of the tanning materials $[24,25]$. It is therefore expected that the extract recovered from samples under investigation at $50{ }^{\circ} \mathrm{C}$ is likely to perfom better in tanning than others, thereby bringing about desired tanning capacity.

Previous studies reported the loss of tannins, especially hydrolysable ones, when temperature of extraction is above $65^{\circ} \mathrm{C}$ since these tannins tend to decompose at elevated temperatures $[6,26]$. It has also been reported that extraction at elevated temperatures can lead to coextraction of carbohydrates including gums and pectins in undesirable quantities [26]. Thus, tannins from the root and stem barks of T. burttii obtained at $50^{\circ} \mathrm{C}$ or lower could be considered in preparation of such vegetable tannins be it hydrolysable or condensed.

It is also important to note that, like other tannin sources, extraction of tannins from $T$. burttii root and stem barks is possible using water as a sole solvent, which proved to be effective in tanning capacity as discussed in the subsequent section. Use of water for tannin production is cost effective and environmentally safe for sustainable manufacturing of leather [6, 27]. The only limitation would be the quantity of water consumed during extraction, whereby large quantity is required to achieve the intended goal. Despite this limitation, water is still a solvent of choice for tannins preparation at industrial scale [27, 28]. Furthermore, extraction with water leads to slightly acidic extract [27] principally matching with $\mathrm{pH}$ for the maximum crosslinking ability as described in the next section of this article. Hence no acidification is required prior to tanning.

\subsection{The extract yield, tannin content, total phenolic and flavonoid contents of the Tessmannia burttii extracts}

Table 2 presents the extract yield, tannin content, total phenolic content, total flavonoid content and non-solubles present in the $T$. burttii extracts leached at $50{ }^{\circ} \mathrm{C}$. The extracts yield of both stem and root barks were found to be below that of $A$. mearnsii. However, they are within the ranges of other recommended tannin source materials [15, 29]. The tannin content of the stem bark of the studied plant is lower than that of $A$. mearnsii, but higher than recommended value, which is $10 \%$ [30]. On the other hand, the total phenolic and flavonoid contents is higher than that of $A$. mearnsii. Tannins contain phenolic and flavonoid compounds that carry reactive groups to bind collagen fibers during tanning [31]. Presence of sufficient quantity of these ingredient is the key to the successful tanning process [15]. Having phenolic and flavonoid content in a quantity higher in T. burtii stem bark extract than commercial source of tannin, A. mearnsii, is an evident that T. burttii extracts can be a suitable source for tannins production.

Table 1 The interval between $T_{\text {onset }}$ and $T_{\text {peak }}$ of hide powder cross-linked with extract of Tessmannia burttii and Acacia mearnsii at $\mathrm{pH} 5$ in dependence of Temperature of extraction

\begin{tabular}{|c|c|c|c|c|c|c|c|}
\hline \multirow{3}{*}{$\begin{array}{l}\text { Extraction } \\
\text { temperature } \\
\left({ }^{\circ} \mathrm{C}\right)\end{array}$} & \multicolumn{7}{|c|}{ Denaturation temperature $\left({ }^{\circ} \mathrm{C}\right)$} \\
\hline & \multicolumn{3}{|c|}{ T. burttii stem bark } & \multicolumn{2}{|c|}{ T. burttii root bark } & \multicolumn{2}{|l|}{ A. mearnsii stem bark } \\
\hline & $T_{\text {onset }}$ & $\mathrm{T}_{\text {peak }}$ & Interval ( $\left.T_{\text {peak }}-T_{\text {onset }}\right)$ & $\mathrm{T}_{\text {onset }}$ & $T_{\text {peak }}$ & Interval ( $\left.\mathrm{T}_{\text {peak }}-\mathrm{T}_{\text {onset }}\right)$ & Interval $\left(T_{\text {peak }}-T_{\text {onset }}\right)$ \\
\hline 30 & $81.16 \pm 0.57$ & $85.64 \pm 0.05$ & 4.48 & $80.93 \pm 0.09$ & $85.42 \pm 0.20$ & 4.49 & 3.44 \\
\hline 50 & $81.62 \pm 0.41$ & $85.36 \pm 0.14$ & 3.75 & $81.47 \pm 0.22$ & $85.22 \pm 0.22$ & 3.75 & 3.71 \\
\hline 80 & $81.34 \pm 0.07$ & $85.36 \pm 0.40$ & 4.02 & $81.18 \pm 0.00$ & $85.34 \pm 0.01$ & 4.16 & 3.83 \\
\hline
\end{tabular}


Table 2 Tannin content, total phenolic content and total flavonoid content of the T. burttii extracts extracted at $50^{\circ} \mathrm{C}$

\begin{tabular}{lllll}
\hline Plant & Extract yield (\%) & Tannin content (\%) & Total phenolic content (\%) & Total flavonoid content (\%) \\
\hline Tesmmannia burttii & $39.4 \pm 1.0$ (stem bark) & $61.2 \pm 0.2$ & $58.5 \pm 1.0$ & $32.8 \pm 0.0$ \\
& $32.4 \pm 1.2$ (root bark) & & & $22.5 \pm 0.1$ \\
Acacia mearnsii stem bark & $56.02 \pm 0.3$ & 84.3 & $32.8 \pm 0.5$ & 2.5 \\
\hline
\end{tabular}

${ }^{a}$ Tessmannia burtii root bark extract was not analysed for tannin content, total phenolic and flavonoid contents due to limited amount of resources

\subsection{The interaction mechanism between vegetable} tannins from Tessmannia burttii and collagen of the hide Interactions between tannins and protein have been studied for more than 50 years because of their unique characteristics and potential use in various industries [32]. Recently, the study on the interaction of tannins with collagen of the skin has also gained attention due to the role that vegetable tannins play in attaining green production and eco-friendly tanning goals. Similary, the The present work studied the interaction mechanism between collagen of the hide powder and the tannins from the root and stem bark of T. burttii by employing three different methods. The purpose was to understand the underlying chemistry and confirming the tannins type. To achieve this purpose, hide powder were treated with extracts under the same conditions. The treated hide powder was analyzed for denaturation temperature at different $\mathrm{pH}$ using DSC technique, amount of crosslinked amines at basic $\mathrm{pH}$ before acid hydrolysis and after acid hydrolysis using TNBS acid assay and amino acid analysis, respectively.

\subsubsection{DSC analysis}

The results for DSC analysis are presented in Fig. 2a and $\mathrm{b}$, where denaturation temperature denotes the extent of interaction/crosslinking activity of tannins on the hide powder collagen. It was noted that the crosslinking activity was sharply increasing from lower $\mathrm{pH}$ towards high $\mathrm{pH}$ up to 4, above which the denaturation temperature remained constant (Fig. 2a). Similar trend was observed for A. mearnsii (Fig. 2b). This indicates that binding preferentially occurs at unprotonated amino groups via nucleophilic addition reaction [33-35], which gives a first hint, that T.burtii contains mainly condensed tanning agents. The DSC measurements were performed in a buffer at $\mathrm{pH}$ 7. All purely electrostatic interactions with protonated amino groups are preferably eliminated at this $\mathrm{pH}$ value, which would be the case with hydrolysable tanning agents. This and the increasing cross-linking activity with increasing $\mathrm{pH}$ value suggest the presence of mainly condensed tanning agents.

With hydrolysable tannins preferentially hydrogen bonding occurs when phenolic hydroxyl interacts with protonated amino group or peptide oxygen of collagen $[9,26]$. Since at acid $\mathrm{pH}$ less than 4 the interaction observed was low, it might be inferred that tannins in the investigated samples contain fewer hydroxy groups to form hydrogen bond with collagen. It has been reported that high crosslinking activity observed at neutral basic $\mathrm{pH}$ is mainly due to covalent bonding between unprotonated amino groups in the collagen and either quinone or aldehyde groups in the tannin molecule [9, 36, 37]. Thus, TNBS acid assay was performed in this work to indicate possible presence of the covalent bonding due to the interaction between tannins and unprotonated amino groups.

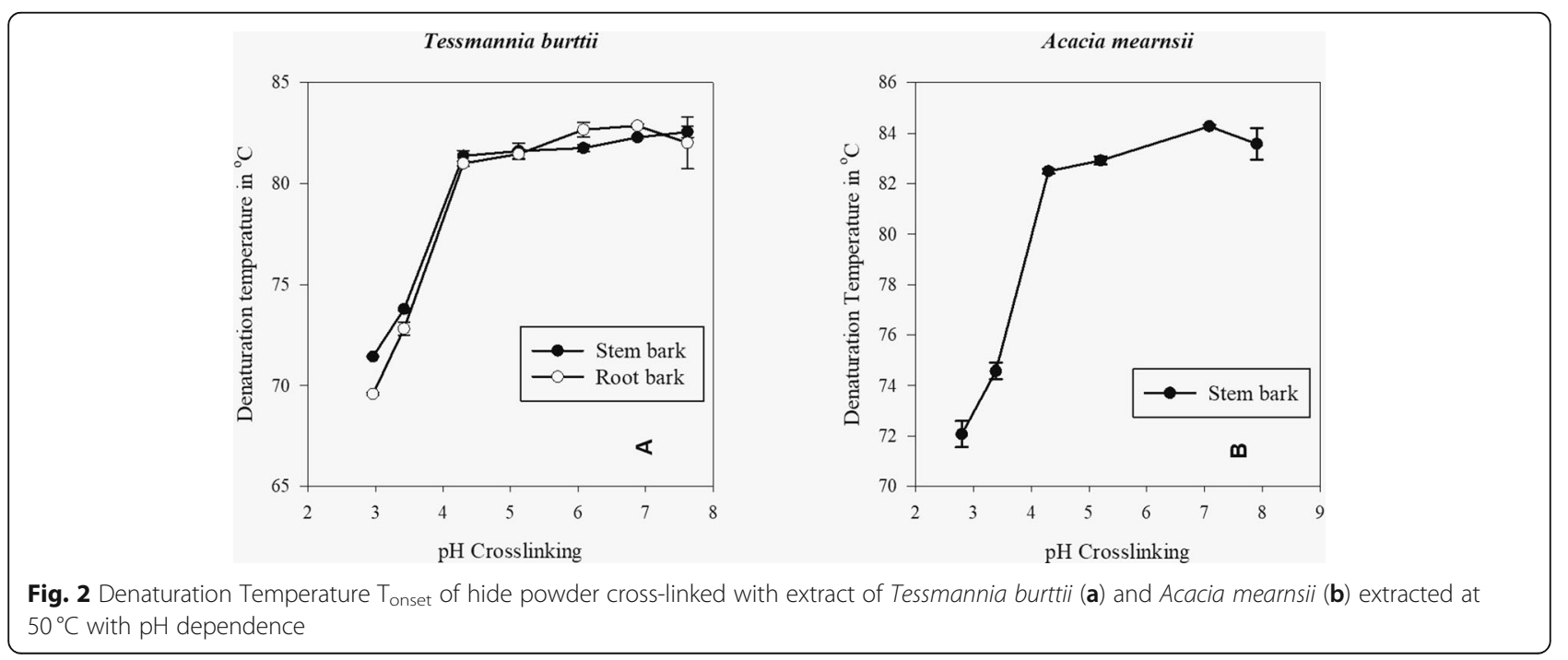




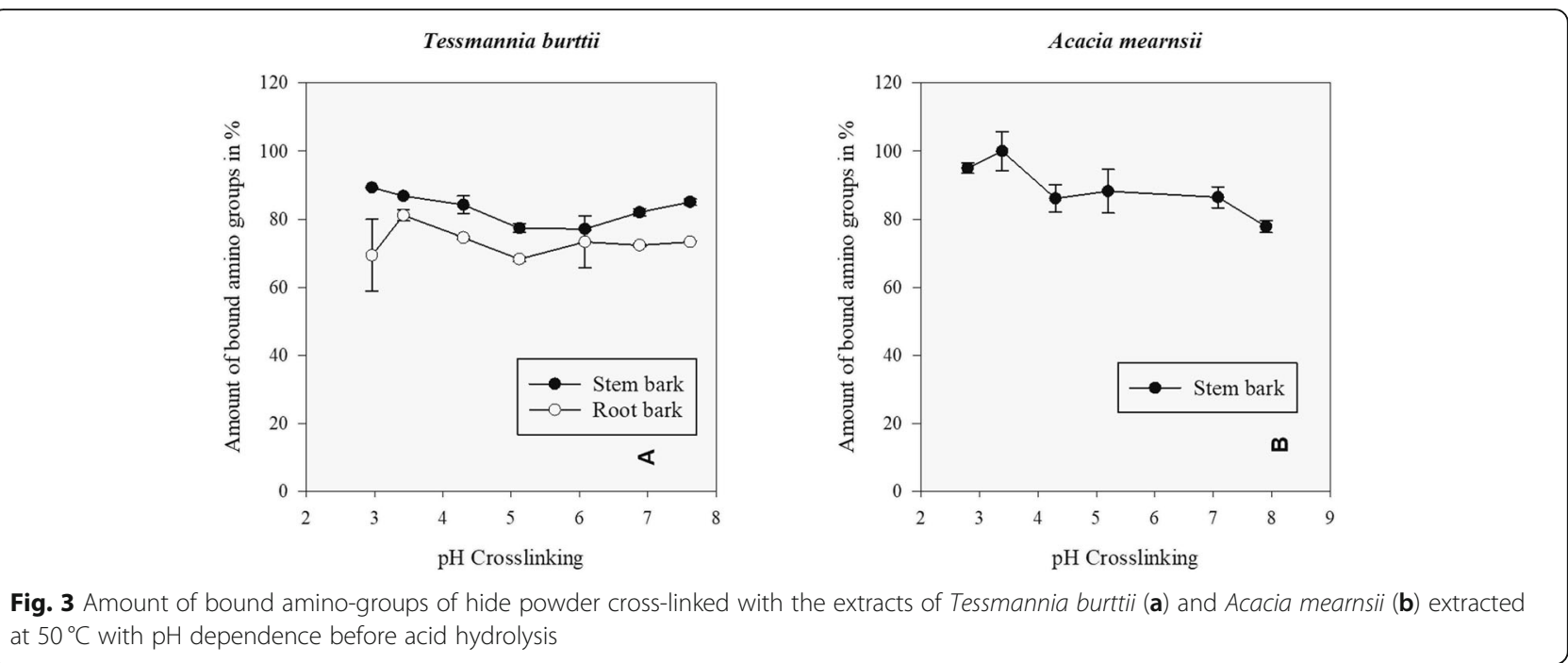

\subsubsection{TNBS acid assay}

Since DSC results revealed probable formation of covalent bonds that occurred at $\mathrm{pH}$ above 4 , it was essential to characterize the amount of amino groups that participated in the crosslinking activity. The crosslinked hide powder were derivertised with TNBS acid and their percentage crosslinked is presented in Fig. 3a and b. Tannins from stem bark revealed high amount of crosslinked amino groups even for the samples treated at acidic pH. Root bark tannins showed significant amount of crosslinked amino groups, but were slightly low at acidic $\mathrm{pH}$ (Fig. 3a). A. mearnsii extracts which belong to condensed tannins exhibited similar trend (Fig. 3b). Previous investigations have also acknowledged the presence of interactions between tannins and amino groups of protein preferentially at neutral to alkaline $\mathrm{pH}[9,15,32]$.

According to Zhang et al., the postulated chemical pathway for covalent bond formation between unprotonated amino groups and tannins involves initial oxidization of phenolic structures to form quinone intermediates under alkaline conditions that can readily react with nucleophiles from reactive amino acid groups in protein chain [38]. On the other hand, glutaldelyde and secoiridoids have also been reported to depict a similar trend except that the reactive group in these two compounds is aldehyde and not quinones as it is the case for condensed tannins $[9,36,37]$. To differentiate between the two possible crosslinking mechanisms, one must undertake amino acid hydrolysis on the crosslinked collagen material based on the fact that the bonds formed due to quinone are not stable on acid hydrolysis as opposed to those due to aldehyde $[9,36,37]$.

\subsubsection{Amino acid hydrolysis}

To implicitly determine whether the formation of covalent linkages between tannins from studied plant extracts powder and hide powder collagen was due to either quinone or aldehyde groups, amino acid hydrolysis method was employed. As for A. mearnsii treated hide powder (Fig. 4b), high percent of crosslinked amino groups observed in TNBS acid assay dropped to less than $2 \%$ for both root and stem bark extracts treated hide powder (Fig. 4a). These few crosslinks observed might be due to electrostatic interactions. As it was pinpointed earlier, the interaction of this nature is characteristic of condensed tannins of A. mearnsii. In our previous work we had similar observation for the extracts from three plants namely Acacia xanthophloea, Euclea divinorum and E. racemosa [15]. Therefore, it can be concluded that $T$. burttii contain condensed tannins, being in agreement with already identified catechinoids from the same plant stem and root barks (unpublished work). This is good for production of durable and thermally stable leather as previuosly confirmed that covalent bonds between phenolic compounds and proteins are more rigid and thermally stable than other interactions [38].

\section{Conclusions}

The present work reports the investigation of the crosslinking capacity of the extracts (tannins) from stem and root barks of $T$. burttii as a function of extraction temperature and $\mathrm{pH}$. The work was further extended to study the corresponding interaction mechanism between the extracts with collagen of the skin in comparison to $A$. mearnsii extracts. The 

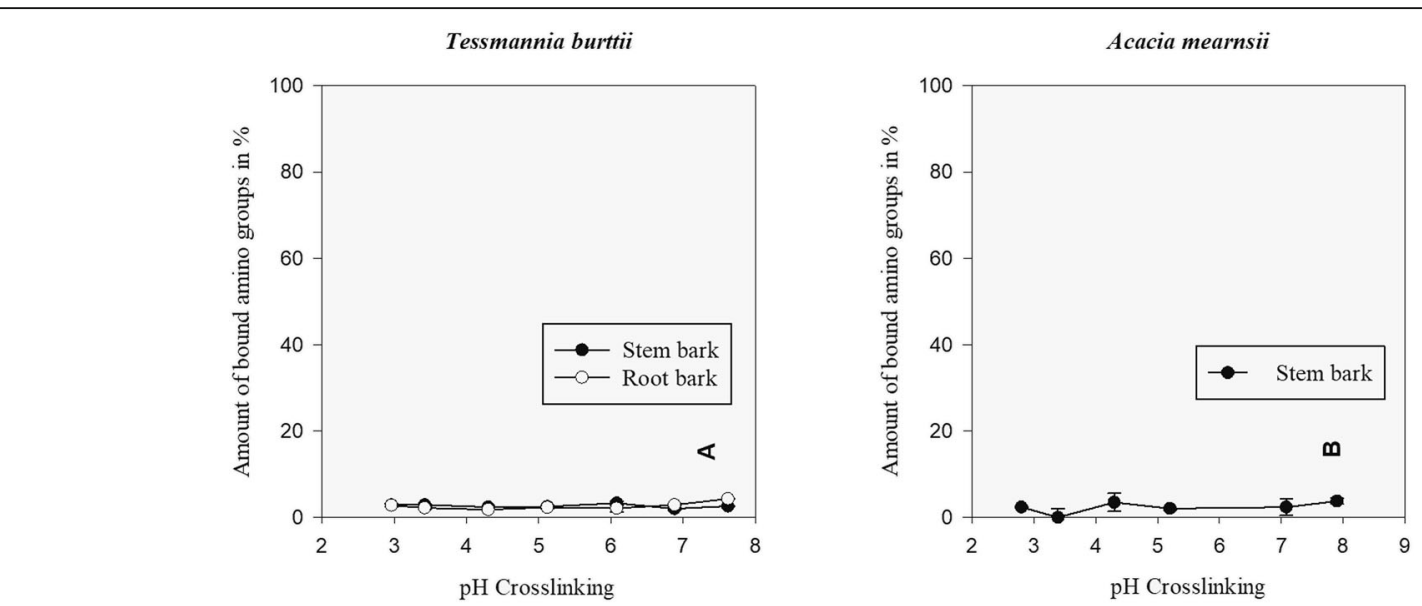

Fig. 4 Amount of bound amino-groups of hide powder cross-linked with the extracts of Tessmannia burttii (a) and Acacia mearnsii (b) extracted at $50^{\circ} \mathrm{C}$ with $\mathrm{pH}$ dependence after acid hydrolysis

extraction temperature exhibited little effect on crosslinking capacity, but extraction at $50^{\circ} \mathrm{C}$ yielded the best results in relation to $\mathrm{T}_{\text {onset }}$ to $\mathrm{T}_{\text {peak }}$ interval. The extract yield is within the recommended range while the tannin content is above the recommended values. T. burtii stem bark extract total phenolic and flavonoid contents are above that of commercial source, $A$. mearnsii. Minimum $\mathrm{pH}$ for the maximum crosslinking capacity was established to be 4 . The study has established that the interaction between the studied tannins with collagen of the skin could preferentially occur via covalent bonding with basic amino groups and the bonds formed are not stable upon acid treatment. Based on the nature of tannin-collagen interactions, the observations that were comparable to those of $A$. mearnsii extract used as a reference, it was ascertained that tannins from both stem and root barks of $T$. burttii belong to condensed type. Therefore, T. Burttii extracts have the same tanning potential as $A$. mearnsii. Considering the environmental aspects, this work has uncovered a promising alternative eco-friendly source of vegetable tannins deployable in sustainable leather manufacturing. Further investigatory parameters on their cross-linking capacity such as structural characterization, and participation of the carboxyl and guanidino groups in the reaction are highly recommended.

\section{Acknowledgements}

Authors wish to thank Michael Kramer and Heidrun Berthold for technical assistance during laboratory work. Mr. Frank M. Mbago, a senior taxonomist and curator at the Herbarium of the Department of Botany, University of Dar es Salaam is highly appreciated for locating and identifying the plant species reported in this investigation.

\section{Authors' contributions}

SSN, MS and CRC conceptualized the research. MS designed experiments to collect data. CRC and MMM drafted the manuscript and edited all corrections and comments from co-authors. The rest of the authors participated fully in reviewing and editing the manuscript. The author(s) read and approved the final manuscript.

\section{Funding}

J.J.E.M. is grateful to the International Foundation for Sciences (IFS) [grant numbers Grant No. J/5528-1] for financial support involved in the plant collection.

\section{Availability of data and materials}

The datasets used and/or analysed during the current study are available from the corresponding author on reasonable request.

\section{Declaration}

\section{Competing interests}

The authors declare that they have no competing interests.

\section{Author details}

'Division of Textile and Leather Technologies, Tanzania Industrial Research and Development Organization, P. O. Box 2355, Dar es Salaam, Tanzania.

${ }^{2}$ Chemistry Department, College of Natural and Applied Sciences, University of Dar es Salam, P.O. Box 35061, Dar es Salaam, Tanzania. ${ }^{3}$ Department of Environmental Planning, Institute of Rural Development Planning (IRDP), P.O. Box 138, Dodoma, Tanzania. ${ }^{4}$ FILK - Research Institute of Leather and Plastic Sheeting, Meißner Ring 1-5, 09599 Freiberg, Germany.

Received: 28 July 2020 Accepted: 15 March 2021

Published online: 15 May 2021

\section{References}

1. China CR, Maguta MM, Nyandoro SS, Hilonga A, Kanth SV, Njau KN. Alternative tanning technologies and their suitability in curbing environmental pollution from the leather industry: a comprehensive review. Chemosphere. 2020;254:126804.

2. Unango FJ, Duraisamy R, Ramasamy KM. A review of eco-friendly preservative and bio-tannin materials using powdered barks of local plants for the processing of goatskin. Int Res J Sci Technol. 2019;1 (1):13-20.

3. Prokein M, Renner M, Weidner E, Heinen T. Low-chromium-and lowsulphate emission leather tanning intensified by compressed carbon dioxide. Clean Techn Environ Policy. 2017;19(10):2455-65. https://doi.org/1 0.1007/s10098-017-1442-x.

4. Bacardit A, Combalia F, Font J, Baquero G. Comparison of the sustainability of the vegetable, wet-white and chromium tanning processes through the life cycle analysis. J Am Leather Chem Assoc. 2020;115(03):105-11.

5. Auad P, Spier F, Gutterres M. Vegetable tannin composition and its association with the leather tanning effect. Chem Eng Commun. 2020; 207(5):722-32. https://doi.org/10.1080/00986445.2019.1618843. 
6. Fraga-Corral M, García-Oliveira P, Pereira AG, Lourenço-Lopes C, Jimenez Lopez C, Prieto MA, Simal-Gandara J. Technological application of tanninbased extracts. Molecules. 2020;25(3):614. https://doi.org/10.3390/ molecules25030614.

7. Covington AD. Tanning chemistry: the science of leather: Cambridge: Royal Society of Chemistry; 2009.

8. Hussain SA, Sulaiman AA, Alhaddad H, Alhadidi Q. Natural polyphenols: influence on membrane transporters. J Intercult Ethnopharmacol. 2016;5(1): 97-104. https://doi.org/10.5455/jice.20160118062127.

9. Schroepfer $M$, Meyer M. Investigations towards the binding mechanisms of vegetable tanning agents to collagen. Res J Phytochem. 2016;10(2):58-66. https://doi.org/10.3923/rjphyto.2016.58.66.

10. Mohammed SA, Naisini A, Madhan B, Demissie BA. Rumex abyssinicus (mekmeko): a newer alternative for leather manufacture. Environ Prog Sustain Energy. 2020;39(6). https://doi.org/10.1002/ep.13453.

11. Mutiar S, Asben A. Quality of leather using vegetable tannins extract of Acacia mangium bark from waste of industrial plantation. IOP Conference Ser: Earth and Environmental Science. 2019;327(1):012012.

12. Nalyanya KM, Rop R, Onyuka A, Birech Z. Recent use of selected phytochemistry to mitigate environmental challenges facing leather tanning industry: a review. Phytochem Rev. 2019;18(5):1361-73. https://doi. org/10.1007/s11101-019-09651-X.

13. Eltom E, Abdalla G. Extracting and studying the factors affecting the tanning material in the Garad pods. Int Res J Pure Appl Chem. 2020:6-16. https://doi.org/10.9734/irjpac/2020/v21i430161

14. Cardon D. Dyes and tannins: Netherlands: PROTA; 2005

15. China CR, Hilonga A, Nyandoro SS, Schroepfer M, Kanth SV, Meyer M, Njau KN. Suitability of selected vegetable tannins traditionally used in leather making in Tanzania. J Clean Prod. 2020;251:119687. https://doi.org/10.1016/j. jclepro.2019.119687.

16. Mligo C, Lyaruu H, Ndangalasi $H$, Marchant R. Vegetation community structure, composition and distribution pattern in the Zaraninge Forest, Bagamoyo District, Tanzania. J East Afr Nat Hist. 2009;98(2):223-39. https:// doi.org/10.2982/028.098.0204

17. Léonard J. Notulae systematicae IV (Caesalpiniaceae-Amherstieae africanae americanaeque). Bull du Jardin Botanique de l'État a Bruxelles. 1949;19(Fasc. 4):383-408.

18. Cuong DX, Hoan NX, Dong DH, Van Thanh N, Ha HT, Tuyen DTT, et al. Tannins: extraction from plants. Tannins-structural properties, biological properties and current knowledge: London: IntechOpen; 2019.

19. WRAaFC T. In: E. \& F. N. spon Ltd, editor. Porter's leather chemists' pocketbook: a short compendium of analytical method. 3rd ed; 1937

20. Blainski A, Lopes GC, De Mello JCP. Application and analysis of the folin ciocalteu method for the determination of the total phenolic content from Limonium brasiliense L. Molecules. 2013;18(6):6852-65. https://doi.org/10.33 90/molecules18066852

21. Kamtekar S, Keer V, Patil V. Estimation of phenolic content, flavonoid content, antioxidant and alpha amylase inhibitory activity of marketed polyherbal formulation. J Appl Pharmaceut Sci. 2014;4(9):61.

22. Breck $O$, Bjerkås $E$, Campbell $P$, Rhodes J, Sanderson J, Waagbø R. Histidine nutrition and genotype affect cataract development in Atlantic salmon, Salmo salar L. J Fish Dis. 2005;28(6):357-71. https://doi.org/10.1111/j.1365-2 761.2005.00640.x.

23. Zalacain A, Prodanov M, Carmona M, Alonso G. Optimisation of extraction and identification of gallotannins from sumac leaves. Biosyst Eng. 2003; 84(2):211-6. https://doi.org/10.1016/S1537-5110(02)00246-5.

24. Choudhury SD, DasGupta S, Norris GE. Unravelling the mechanism of the interactions of oxazolidine $A$ and $E$ with collagens in ovine skin. Int J Biol Macromol. 2007;40(4):351-61. https://doi.org/10.1016/j.ijbiomac.2006.09.003.

25. Tang H, Covington A, Hancock R. Use of DSC to detect the heterogeneity of hydrothermal stability in the polyphenol-treated collagen matrix. J Agric Food Chem. 2003;51(23):6652-6. https://doi.org/10.1021/jf034380u

26. Leafe MK. Leather technologists pocket book: East Yorkshire: Society of leather technologists and chemists; 1999.

27. de Hoyos-Martinez PL, Merle J, Labidi J, Charrier-El Bouhtoury F. Tannins extraction: a key point for their valorization and cleaner production. J Clean Prod. 2019;206:1138-55. https://doi.org/10.1016/j.jclepro.2018. 09.243.

28. Aires A. Tannins-structural properties, biological properties and current knowledge; 2020. https://doi.org/10.5772/intechopen.80170.
29. Onem E, Gulumser G, Akay S, Yesil-Celiktas O. Optimization of tannin isolation from acorn and application in leather processing. Ind Crop Prod. 2014;53:16-22. https://doi.org/10.1016/j.indcrop.2013.12.014.

30. Mahdi H, Palmina K, Glavtch I. Characterization of Acacia nilotica as an indigenous tanning material of Sudan. J Trop For Sci. 2006;18:181-7.

31. Chet NW. Total phenolic and total flavonoids content of pitaya peels by water extraction. In: A thesis Faculty of Chemical and Natural Resources Engineering Universiti Malaysia Pahang; 2009.

32. Adamczyk B, Simon J, Kitunen V, Adamczyk S, Smolander A. Tannins and their complex interaction with different organic nitrogen compounds and enzymes: old paradigms versus recent advances. ChemistryOpen. 2017;6(5): 610-4. https://doi.org/10.1002/open.201700113.

33. Endres $\mathrm{H}$. Theory of interaction of vegetable tannins with collagen. Leather Sci. 1964;11:455-62.

34. Bruins JJ, Albada B, van Delft F. Ortho-quinones and analogues thereof: highly reactive intermediates for fast and selective biofunctionalization. Chem Eur J. 2018;24(19):4749-56. https://doi.org/10.1002/chem.201703919.

35. Bittner $\mathrm{S}$. When quinones meet amino acids: chemical, physical and biological consequences. Amino Acids. 2006;30(3):205-24. https://doi.org/1 0.1007/s00726-005-0298-2.

36. Barbut S, loi M. An investigation of the mechanical, microstructural and thermo-mechanical properties of collagen films cross-linked with smoke condensate and glutaraldehyde. Italian J Food Sci. 2019;31(3):644-60.

37. Scope BS, Pretto GL, Postiglione Correa Jl, Baldasso C, Dettmer A, Campomanes Santana RM. Starch-Leather Waste Gelatin Films Cross-Linked with Glutaraldehyde. J Polymers Environ. 2020;28:1974-84.

38. Zhang X, Do MD, Casey P, Sulistio A, Qiao GG, Lundin L, Lillford P, Kosaraju $S$. Chemical cross-linking gelatin with natural phenolic compounds as studied by high-resolution NMR spectroscopy. Biomacromolecules. 2010; 11(4):1125-32. https://doi.org/10.1021/bm1001284

\section{Publisher's Note}

Springer Nature remains neutral with regard to jurisdictional claims in published maps and institutional affiliations.

\section{Submit your manuscript to a SpringerOpen ${ }^{\circ}$ journal and benefit from:}

- Convenient online submission

- Rigorous peer review

- Open access: articles freely available online

- High visibility within the field

- Retaining the copyright to your article

Submit your next manuscript at $>$ springeropen.com 